\title{
Phenolic content and antioxidant property of the bark extracts of Ziziphus mucronata Willd. subsp. mucronata Willd
}

\author{
Olufunmiso O Olajuyigbe and Anthony J Afolayan*
}

\begin{abstract}
Background: Several plants traditionally used in treatment of a variety of infections in South Africa are reported in ethnobotanical surveys. Many of these plants including Ziziphus mucronata subsp. mucronata lack scientific reports to support their medicinal importance.

Methods: The antioxidant activities and phenolic contents of the acetone, ethanol and aqueous extracts of the stems of Z. mucronata subsp. mucronata were evaluated using in vitro standard methods. The total phenol, total flavonoids and proanthocyanidin content were determined spectrophotometrically. Quercetin, Tannic acid and catechin equivalents were used for these parameters. The antioxidant activities of the stem bark extracts of this plant were determined by ABTS, DPPH, and ferrous reducing antioxidant property (FRAP) methods.
\end{abstract}

Results: The quantity of the phenolic compounds, flavonoids and proanthocyanidins detected differ significantly in the various extracts. The phenolics were significantly higher than the flavonoids and proanthocyanidin contents in all the extracts investigated. The ferric reducing ability and the radical scavenging activities of the extracts were very high and dose-dependent. The ethanol extract had the highest antioxidant activity, followed by the acetone extract while the aqueous extract was the least active. Reacting with ABTS, the $50 \%$ inhibitory concentrations $\left(\mathrm{IC}_{50}\right)$ were $(0.0429 \pm 0.04 \mathrm{mg} / \mathrm{ml})$ for aqueous, $(0.0317 \pm 0.04 \mathrm{mg} / \mathrm{ml})$ for acetone and $(0.0306 \pm 0.04 \mathrm{mg} / \mathrm{ml})$ for ethanol extracts while they inhibited DPPH radical with $50 \%$ inhibitory concentration $\left(I C_{50}\right)$ values of $0.0646 \pm 0.02 \mathrm{mg} / \mathrm{ml}$ (aqueous), $0.0482 \pm 0.02 \mathrm{mg} / \mathrm{ml}$ (acetone) and $0.0422 \pm 0.03 \mathrm{mg} / \mathrm{ml}$ (ethanol).

Conclusions: A correlation between the antioxidant activity and the total phenolic contents of the extracts indicated that phenolic compounds were the dominant contributors to the antioxidant activity of the plant. This study, therefore, demonstrated that Z. mucronata subsp. mucronata has strong antioxidant property and free radical scavenging capability.

\section{Background}

Free radicals and reactive oxygen species (ROS) such as superoxide, hydroxyl and peroxyl radicals are normal by-products of aerobic metabolism produced in vivo during oxidation [1]. These ROS are generated in the mitochondria and microsome organelles under normal physiological conditions. They can also be produced externally by exposure to radiation, toxic chemicals, cigarette smoking and alcohol consumption, and by eating oxidized polyunsaturated fats. Overproduction of

\footnotetext{
* Correspondence: Aafolayan@ufh.ac.za

Phytomedicine Research Centre, Department of Botany, University of Fort
} Hare, Alice, 5700, South Africa
ROS can result in oxidative damage to various biomolecules including lipids, proteins, DNA and cell membranes [2]. They also lead to the development of a variety of diseases such as coronary heart diseases, cancer, diabetes, hypertension and neurodegeneration [3,4]. While compounds capable of scavenging free radicals possess great potential in ameliorating these diseases $[5,6]$, most of the ROS are scavenged by endogenous defense enzymes such as catalase, superoxide dismutase and peroxidase-glutathione system [7]. However, the activities of these endogenous defense systems may not be sufficient to mop up the free radicals.

Commonly used synthetic antioxidants include butylated hydroxyanisole (BHA), butylated hydroxytoluene

\section{Biomed Central}


(BHT), propylgallate (PG) and tertbutylhydroxyltoluene (TBHQ) [8]. Though important, they are known to constitute potential health risks and toxic effects [9]. Their applications are, therefore, strongly restricted. Hence, the need to search, develop and utilize more effective antioxidant from natural origin [10]. The medicinal properties of many plants have been attributed to the antioxidant properties of their constituents [11]. Some epidemiological studies also showed that the consumption of some plants can protect humans against oxidative damage by quenching free radicals and ROS $[12,13]$. Today, there are overwhelming interests in finding naturally occurring antioxidants for use in foods and in medicinal materials to replace synthetic antioxidants [14]. Interests in plant materials that are rich in phenols are increasing among scientists, food manufacturers and consumers because these materials retard oxidative degradation of lipids and improve the quality and nutritional value of food. People tend to eat functional foods with specific health benefits. The roles of natural antioxidants, mainly phenolic compounds, believed to have more antioxidant activity than vitamins $\mathrm{C}, \mathrm{E}$ and $\beta$-carotene [15] is rapidly gaining attention.

Ziziphus mucronata Willd. subsp. mucronata Willd., also known as buffalo thorn, is a small to medium-sized tree, with a spreading canopy. It is distributed throughout the summer rainfall areas of sub-Saharan Africa, extending from South Africa northwards to Ethiopia and Arabia. Its bark and roots are used medicinally for the treatment of various ailments, including rheumatism, gastrointestinal complaints and snake bites [16]. Warm bark infusions are used for body pains, expectorants in cough, respiratory infections and chest problems. The root infusions are used for treating gonorrhea, diarrhoea and dysentery. Decoctions of roots and leaves are applied externally to boils, sores and glandular swellings not to promote healing but for pain relief $[17,18]$. While several species of the genus Ziziphus have been investigated, there is a dearth of information on the phytochemical property and antioxidant activities of this plant. Hence, in line with the current trend of finding naturally occurring antioxidants, this study was designed to investigate the phenolic contents and antioxidant potential of different extracts of Ziziphus mucronata subsp. mucronata to justify its ethnomedicinal importance.

\section{Methods}

\section{Collection of plant material}

The bark materials of $Z$. mucronata subsp. mucronata were collected from the plant growing within the University of Fort Hare campus in Alice, South Africa. The plant was authenticated in the Department of Botany by Prof. Grierson and a voucher specimen (OLAJ/2010/
ZM/01) was prepared and deposited in the Griffin's Herbarium of the University.

The bark samples were air-dried at room temperature and pulverized using a milling machine. Portions of about $100 \mathrm{~g}$ each of the pulverized samples were extracted separately with $500 \mathrm{ml}$ of each of the solvents, acetone, ethanol and water, for $48 \mathrm{~h}$. The extracts were filtered through Whatman No. 1 filter paper and evaporated to dryness under reduced pressure at $40^{\circ} \mathrm{C}$ using a rotary evaporator. The filtrate of aqueous extract obtained was quickly frozen at $-40^{\circ} \mathrm{C}$ and dried for $48 \mathrm{~h}$ using a freeze dryer (Savant Refrigerated vapor Trap, RV T41404, USA). The extraction yielded $5.3 \mathrm{~g}$ acetone extract, $14.2 \mathrm{~g}$ ethanol extract and $15.8 \mathrm{~g}$ water extract. The extracts were redissolved in their respective solvents to the required concentrations for the bioassay analysis.

\section{Chemicals and reagents used}

2,2'-azinobis-3-ethylbenzothiazoline-6-sulfonic acid (ABTS) diammonium salt, 1,1-diphenyl-2-picrylhydrazyl (DPPH), butylated hydroxytoluene (BHT), gallic acid, rutin, ascorbic acid (VC), quercetin and $\mathrm{FeCl}_{3}$, were purchased from Sigma Chemical Co. (St. Louis, MO, USA); vanillin was from BDH Chemicals Ltd. (Poole, England) and Folin-Ciocalteu phenol reagent and sodium carbonate were from Merck Chemical Supplies (Darmstadt, Germany). All other chemicals used, including the solvents, were of analytical grade.

\section{Determination of total flavonoids}

Total flavonoids were estimated using the method of Ordonez et al. [19]. Here, $0.5 \mathrm{ml}$ of $2 \% \mathrm{AlCl}_{3}$ ethanol solution was added to $0.5 \mathrm{ml}$ of extract and allowed to stand for $60 \mathrm{~min}$ at room temperature before the absorbance was measured at $420 \mathrm{~nm}$. The extract was evaluated at a final concentration of $1 \mathrm{mg} / \mathrm{ml}$. Total flavonoids content was calculated as quercetin equivalent $(\mathrm{mg} / \mathrm{g})$ using the equation based on the calibration curve: $y=0.025 x, R^{2}=$ 0.9812 , where $x$ is the absorbance and $y$ is the quercetin equivalent (QE).

\section{Determination of total phenol}

The total phenolic content of the extract was determined by the modified Folin-Ciocalteu method [20]. The extract $(1 \mathrm{mg} / \mathrm{ml})$ was mixed with $5 \mathrm{ml}$ of FolinCiocalteu reagent (previously diluted with distilled water $1: 10 \mathrm{v} / \mathrm{v})$ and $4 \mathrm{ml}(75 \mathrm{~g} / \mathrm{l})$ of sodium carbonate. The mixture was vortexed for $15 \mathrm{~s}$ and allowed to stand for $30 \mathrm{~min}$ at $40^{\circ} \mathrm{C}$ for colour development. The absorbance was measured at $765 \mathrm{~nm}$ using a spectrophotometer. The content of total phenolic compounds was expressed as $\mathrm{mg} / \mathrm{g}$ gallic acid equivalent of dry extract sample using the equation obtained from the calibration curve: 
$y=0.1216 x, R^{2}=0.9365$, where $\times$ is the absorbance and $y$ is the tannic acid equivalent (GAE).

\section{Determination of total proanthocyanidins}

The procedure reported by Sun et al. [21] was used in the determination of the total proanthocyanidins. A volume of $0.5 \mathrm{ml}$ of $0.1 \mathrm{mg} / \mathrm{ml}$ extract solution was mixed with $3 \mathrm{ml}$ of $4 \%$ vanillin-methanol solution and $1.5 \mathrm{ml}$ hydrochloric acid. The mixture was allowed to stand for 15 min while the absorbance was measured at $500 \mathrm{~nm}$. Total proanthocyanidin content was expressed as catechin equivalents $(\mathrm{mg} / \mathrm{g})$ using the equation based on the calibration curve: $y=1.8223 x+0.0157, R^{2}=0.7246$, where $\times$ is the absorbance and $y$ is the catechin equivalent (CE).

\section{Determination of ferric reducing power}

A spectrophotometric method [22] was used for the measurement of reducing power. The different concentrations of the extracts and the standards, rutin and BHT $(0.02-0.10 \mathrm{mg} / \mathrm{ml} ; 1 \mathrm{ml})$ were mixed with phosphate buffer $(2.5 \mathrm{ml}, 0.2 \mathrm{M}, \mathrm{pH} 6.6)$ and potassium ferricyanide $\left[\mathrm{K}_{3} \mathrm{Fe}(\mathrm{CN})_{6}\right](2.5 \mathrm{ml}, 1 \% \mathrm{w} / \mathrm{v})$. The mixture was incubated at $50^{\circ} \mathrm{C}$ for $20 \mathrm{~min} .2 .5 \mathrm{ml}$ of trichloroacetic acid (TCA) $(10 \% \mathrm{w} / \mathrm{v})$ was added to the mixture which was centrifuged at $1000 \mathrm{rpm}$ for $10 \mathrm{~min}$. The upper layer of the solution $(2.5 \mathrm{ml})$ was mixed with $2.5 \mathrm{ml}$ distilled water and $0.5 \mathrm{ml}$ of $(0.1 \% \mathrm{w} / \mathrm{v}) \mathrm{FeCl}_{3}$. While the absorbance was measured at $700 \mathrm{~nm}$ in a spectrophotometer, increasing absorbance of the reaction mixture indicated greater reducing power of the samples [23].

\section{DPPH radical scavenging assay}

For DPPH assay, the method of Liyana-Pathirana and Shadidi [24] was adopted. A solution of $0.135 \mathrm{mM}$ DPPH in methanol was prepared and $1 \mathrm{ml}$ of this solution was mixed with $1 \mathrm{ml}$ of different concentrations of the different extracts. The reaction mixture was vortexed thoroughly and left in the dark at room temperature for $30 \mathrm{~min}$. BHT was used as reference standard while methanol was used as control. Reduction of the stable DPPH radical was used as a marker of antioxidant capacity of $Z$. mucronata subsp. mucronata extracts. The changes in colour from deep-violet to light-yellow were measured at 517 $\mathrm{nm}$ wavelength using $95 \%$ methanolic solution as a reference solution. This was related to the absorbance of the control without the plant extracts. The percentage inhibition of free radical DPPH was calculated from the following equation: \% inhibition $=[$ (absorbance of control absorbance of sample)/absorbance of control] $\times 100 \%$. All the tests were carried out in triplicates. Though the activity is expressed as $50 \%$ inhibitory concentration $\left(\mathrm{IC}_{50}\right)$ $[25,26], \mathrm{IC}_{50}$ was calculated based on the percentage of $\mathrm{DPPH}$ radicals scavenged. The lower the $\mathrm{IC}_{50}$ value, the higher is the antioxidant activity.

\section{ABTS radical scavenging assay}

For ABTS assay, the methods of Johnstone et al., [27] were modified and adopted. The stock solutions included $7 \mathrm{mM}$ ABTS solution and $2.4 \mathrm{mM}$ potassium persulfate solution. The working solution was then prepared by mixing the two stock solutions in equal proportions and allowing them to react for $12 \mathrm{~h}$ at room temperature in the dark. The solution was then diluted by mixing $1 \mathrm{ml} \mathrm{ABTS}{ }^{+}$ solution with $60 \mathrm{ml}$ of methanol to obtain an absorbance of $0.708 \pm 0.001$ units at $734 \mathrm{~nm}$ using the spectrophotometer. $\mathrm{ABTS}^{+}$solution was freshly prepared for each assay. Plant extracts $(1 \mathrm{ml})$ were allowed to react with 1 $\mathrm{ml}$ of the $\mathrm{ABTS}^{+}$solution and the absorbance was taken at $734 \mathrm{~nm}$ after $7 \mathrm{~min}$ using the spectrophotometer. The $\mathrm{ABTS}^{+}$scavenging capacity of the extract was compared with that of butylated hydroxy toluene (BHT). The percentage inhibition was calculated as $I \%=\left[\left(\mathrm{A}_{\text {blank }}-\mathrm{A}_{\text {sample }}\right) /\right.$ $\left.A_{\text {blank }}\right] \times 100$ where $A_{\text {blank }}$ is the absorbance of ABTS radical + methanol used as control; $A_{\text {sample }}$ is the absorbance of ABTS radical + sample extract/standard. All the tests were carried out in triplicates. Though the activity is expressed as $50 \%$ inhibitory concentration $\left(\mathrm{IC}_{50}\right)[25,26]$, $\mathrm{IC}_{50}$ was calculated based on the percentage of ABTS radicals scavenged. The lower the $\mathrm{IC}_{50}$ value, the higher is the antioxidant activity.

\section{Statistical Analysis}

Data were expressed as means \pm standard deviations (SD) of three replicate determinations and then analyzed by SPSS V.16 (Statistical Program for Social Sciences, SPSS Corporation, Chicago, IL). One way analysis of variance (ANOVA) and the Duncan's New Multiple-range test were used to determine the differences among the means. $P$ values $<0.05$ were regarded to be significant. The Pearson correlation analysis was performed between antioxidant activity and total phenolic content.

\section{Results}

\section{Phytochemical compositions}

In this study, the result showed that the amount of total phenolic content, flavonoids and proanthocyanidins differ significantly among the various extracts of the $Z$. mucronata subsp. mucronata (Figure 1). The values of total phenolic contents varied from $24.72 \pm 0.01$ to $31.96 \pm 0.01 \mathrm{mg}$ GAE/100 g dry weight of plant material. The flavonoid contents values ranged from $4.80 \pm 0.01$ to $9.02 \pm 0.01 \mathrm{mg}$ $\mathrm{QE} / 100 \mathrm{~g}$ of dry plant material. The quantity of the proanthocyanidin contents ranged from $1.26 \pm 0.01$ to $2.08 \pm 0.01 \mathrm{mg} \mathrm{CE} / 100 \mathrm{~g}$ of dry plant material. The ethanol extract had the highest total phenolic content values, followed by the acetone extract while water extract contained the least. The highest value of flavonoid was recorded in the acetone extract, followed by the ethanol extract and the water extract. Though proanthocyanidin 


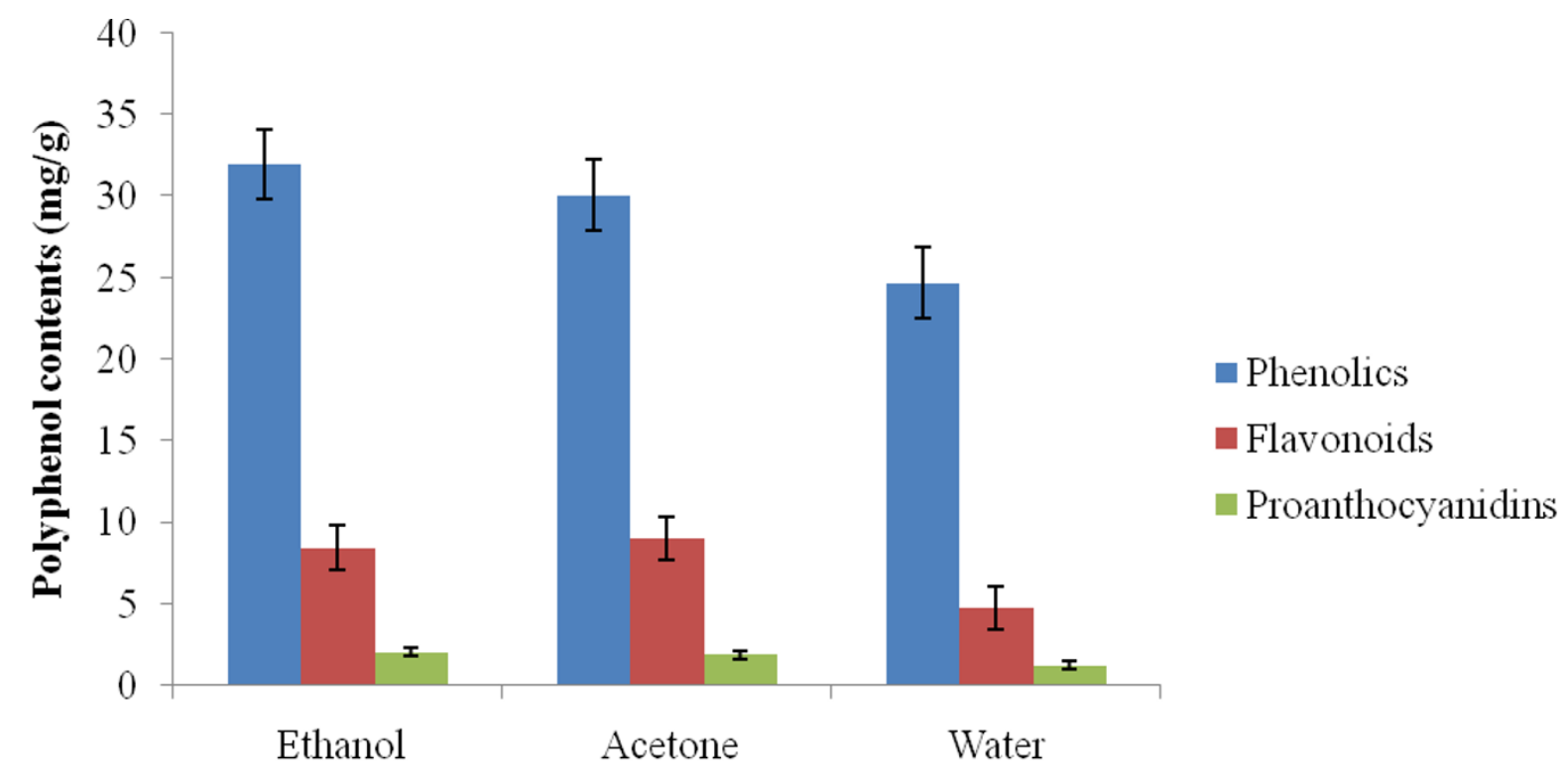

Extracts of $Z$. mucronata

Figure 1 Polyphenolic contents $(\mathbf{m g} / \mathbf{g}$ ) of Ziziphus mucronata subsp. mucronata. Data are presented as means \pm standard deviation of three replicate with significant increases from all samples tested.

was more in ethanol extract than other extracts, the proanthocyanidins content in this plant was relatively low and the differences in its quantity from one extract to another are significant. These results showed that, quantitatively, in Z. mucronata, total phenol contents were significantly higher than the flavonoid contents while the proanthocyanidins were the least.

\section{Ferric Reducing Antioxidant Power (FRAP)}

The FRAP values of different extracts of $Z$. mucronata subsp. mucronata was determined in an attempt to compare their antioxidant activities The reducing abilities of the different extracts determined by FRAP method were measured spectrophotometrically by their absorbances at $700 \mathrm{~nm}$ and summarized in Figure 2. The reducing ability of the extracts showed a dose-dependent trend increasing with increases in the concentrations of the extracts. While highest reducing ability was observed at the highest concentration of each of the extracts, significant differences existed between the reducing ability of each all the extracts. Of the three extracts, acetone extract exhibited the highest reducing capability $(0.454 \pm 0.001)$ at the highest concentration. This was followed by $(0.421 \pm 0.002)$ ethanol extract while aqueous extract $(0.14 \pm 0.002)$ was the least. The reducing abilities recorded was in the following order, Rutin $>\mathrm{BHT}>$ Acetone $>$ Ethanol $>$ Aqueous which showed that rutin exhibited the highest reducing ability at $0.1 \mathrm{mg} / \mathrm{ml}$. The significant differences for free radical scavenging activity among the different extracts may be attributed to the varied quantity of each of the phytochemical contents of the plant.

\section{DPPH radical scavenging activity}

The results of the DPPH scavenging activity of the extracts are as shown in Table 1 . The alcoholic and aqueous extracts of $Z$. mucronata stem bark exhibited concentration dependent antiradical activity by inhibiting $\mathrm{DPPH}$ radical with inhibitory concentration $50 \%\left(\mathrm{IC}_{50}\right)$ values of $0.0646 \pm 0.02 \mathrm{mg} / \mathrm{ml}$ (aqueous), $0.0482 \pm 0.02$ $\mathrm{mg} / \mathrm{ml}$ (acetone) and $0.0422 \pm 0.03 \mathrm{mg} / \mathrm{ml}$ (ethanol) while those of the standards were $0.0406 \pm 0.02 \mathrm{mg} / \mathrm{ml}$ (BHT) and $0.0411 \pm 0.02 \mathrm{mg} / \mathrm{ml}$ (vitamin C). This result agreed with the earlier report of Motalleb et al. [28] which showed that the scavenging effects on the DPPH radical increases sharply with the increasing concentration of the samples and standards to a certain extent. In the order of activity, ethanol had the stronger antioxidant activity $(0.0422 \pm 0.03 \mathrm{mg} / \mathrm{ml})$, followed by acetone extract while the least activity was obtained from aqueous extract. However, all the extracts exhibited significant DPPH free radical scavenging activity comparable to those obtained from the standards used as controls.

\section{ABTS radical scavenging activity}

Significant $\mathrm{ABTS}^{+}$free radical scavenging activity was evident in both alcoholic and aqueous extracts (Table 2). The rate of the decrease in absorbance at $734 \mathrm{~nm}$ depends on the type and amount of antioxidants and the 


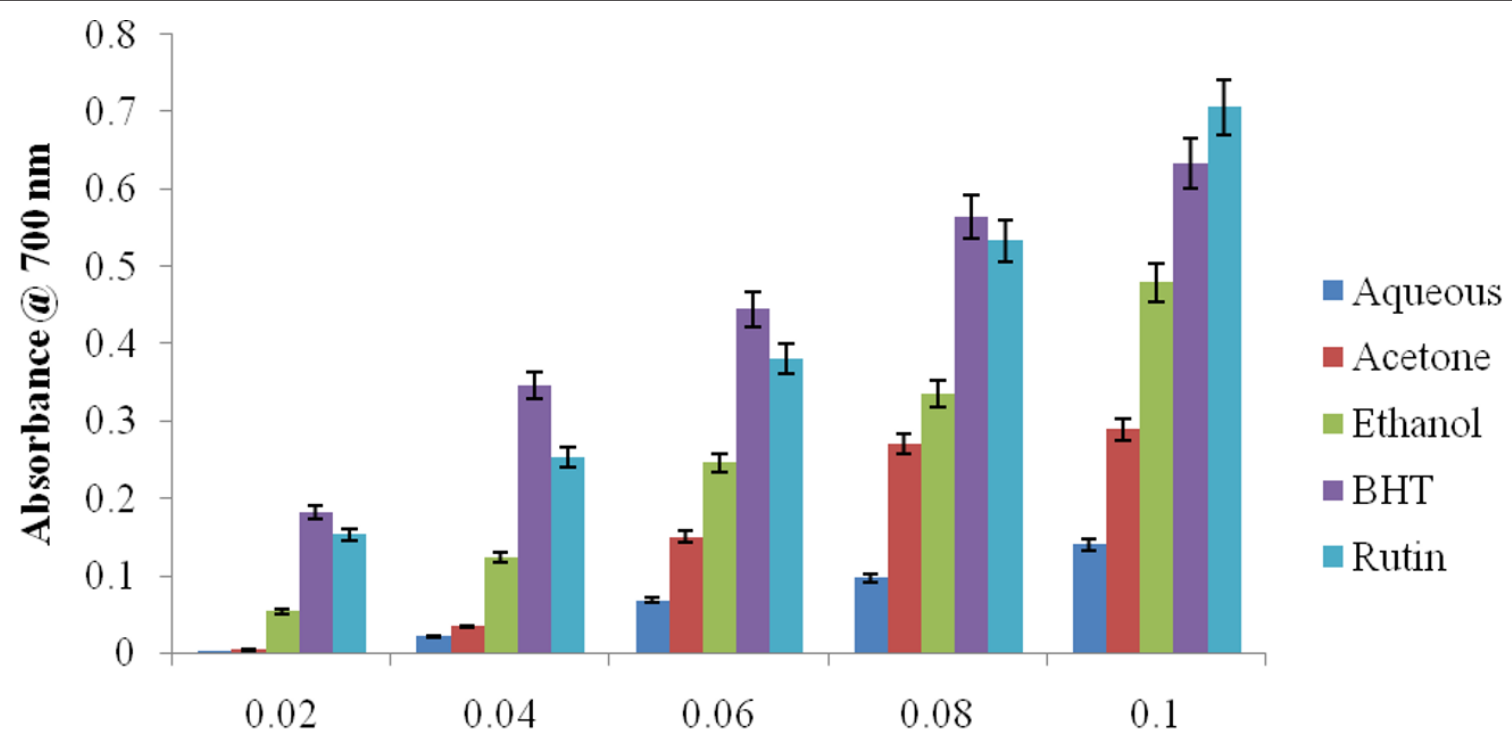

Concentrations of extracts $(\mathrm{mg} / \mathbf{m l})$

Figure 2 Ferric reducing power determinations for the alcoholic and aqueous extracts of $Z$. mucronata subsp. mucronata. Data are presented as means \pm standard deviation of three replicate with significant increases from all samples tested.

results are thus expressed as antioxidant standard equivalents $[29,30]$. In this study, the suppression of the absorbance of $\mathrm{ABTS}^{+}$in a concentration-dependent manner is typically shown by all the extracts. Acetone (97.71 \pm $0.03)$ and ethanol $(95.73 \pm 0.02)$ extracts showed ABTS $^{+}$ radical-scavenging activity higher than the reference standard BHT $(93.47 \pm 0.03)$ and aqueous extracts (88.96 \pm 0.02 ) was lower than that of the BHT. Ethanol extract showed a $50 \%$ inhibitory concentration of $\mathrm{IC}_{50}=0.0306$ $\pm 0.04 \mathrm{mg} / \mathrm{ml}$ while acetone extract showed $\mathrm{IC}_{50}=$ $0.0317 \pm 0.04 \mathrm{mg} / \mathrm{ml}$ which are higher than $\mathrm{IC}_{50}=0.0429$ $\pm 0.04 \mathrm{mg} / \mathrm{ml}$ of the aqueous extract. The differences in the antioxidant activities of the three extracts are statistically significant $(\mathrm{p}<0.05)$.

\section{Discussions}

Phytochemical compositions

Phenolic compounds and flavonoids are the major constituents in most plants reported to possess antioxidant and free radical scavenging activity [31,32]. Phenolic compounds are efficient free radical scavengers [33] exhibiting antioxidant activity by inactivating lipid free radicals, or by preventing the decomposition of hydroperoxides into free radicals [34]. Medicinal plants containing flavonoids exhibit multiple pharmacological activities [35]. Flavonoids, probably the largest of the natural phenolics [36], possess antioxidant properties [37] acting as effective scavenger of deleterious free radicals and reactive oxygen species [38,39]. They have several biological activities including anti-inflammatory, antiallergic and immunomodulatory properties which could help to prevent age-related cardiovascular and neurodegenerative diseases as well as reducing the risk of cancer [40]. Their antioxidant activity depends on the number and location of hydroxyl groups of the flavonoid ring system and the relationship between peroxyl radical absorbing activity and the number of hydroxyl groups in flavonoids [41]. While they act through scavenging or

Table 1 DPPH radical scavenging activity of the alcoholic and aqueous extracts of $Z$. mucronata subsp. mucronata

\begin{tabular}{|c|c|c|c|c|c|c|}
\hline \multicolumn{7}{|c|}{$\%$ inhibitions of $\mathrm{ABTS}^{+} \pm \mathrm{SD}$ at different concentrations of the extracts } \\
\hline Extracts & $0.02(\mathrm{mg} / \mathrm{ml})$ & $0.04(\mathrm{mg} / \mathrm{ml})$ & $0.06(\mathrm{mg} / \mathrm{ml})$ & $0.08(\mathrm{mg} / \mathrm{ml})$ & $0.1(\mathrm{mg} / \mathrm{ml})$ & $\mathrm{IC}_{50}(\mathrm{mg} / \mathrm{ml})$ \\
\hline Aqueous & $9.87 \pm 0.02^{a}$ & $21.86 \pm 0.02^{b}$ & $46.26 \pm 0.02^{c}$ & $62.18 \pm 0.02^{d}$ & $70.34 \pm 0.02^{e}$ & $0.0646 \pm 0.02$ \\
\hline Acetone & $32.67 \pm 0.02^{\mathrm{a}}$ & $39.35 \pm 0.03^{b}$ & $64.49 \pm 0.02^{c}$ & $82.53 \pm 0.03^{d}$ & $88.15 \pm 0.02^{e}$ & $0.0482 \pm 0.02$ \\
\hline Ethanol & $34.35 \pm 0.02^{a}$ & $47.55 \pm 0.03^{b}$ & $71.04 \pm 0.02^{c}$ & $85.06 \pm 0.01^{d}$ & $94.47 \pm 0.02^{e}$ & $0.0422 \pm 0.03$ \\
\hline $\mathrm{BHT}$ & $37.36 \pm 0.02^{\mathrm{a}}$ & $48.50 \pm 0.03^{b}$ & $74.52 \pm 0.01^{c}$ & $92.56 \pm 0.03^{d}$ & $98.47 \pm 0.02^{e}$ & $0.0406 \pm 0.02$ \\
\hline Vitamin C & $23.88 \pm 0.01^{a}$ & $47.65 \pm 0.02^{b}$ & $73.89 \pm 0.03^{c}$ & $90.94 \pm 0.01^{d}$ & $93.01 \pm 0.03^{e}$ & $0.0411 \pm 0.02$ \\
\hline
\end{tabular}

Data are presented as means \pm standard deviation of three replicate with significant increases from all samples tested.

Superscript $a, b, c, d$ and e showed that means \pm standard deviation in the same row with different superscript are significantly different ( $p<0.05$ ) 
Table 2 ABTS radical scavenging activity of the alcoholic and aqueous extracts of $Z$. mucronata subsp. mucronata

\begin{tabular}{|c|c|c|c|c|c|c|}
\hline \multicolumn{7}{|c|}{$\%$ inhibitions of $\mathrm{ABTS}^{+} \pm \mathrm{SD}$ at different concentrations of the extracts } \\
\hline Extracts & $0.02(\mathrm{mg} / \mathrm{ml})$ & $0.04(\mathrm{mg} / \mathrm{ml})$ & $0.06(\mathrm{mg} / \mathrm{ml})$ & $0.08(\mathrm{mg} / \mathrm{ml})$ & $0.1(\mathrm{mg} / \mathrm{ml})$ & $\mathrm{IC}_{50}(\mathrm{mg} / \mathrm{ml})$ \\
\hline Aqueous & $23.95 \pm 0.02^{a}$ & $43.49 \pm 0.06^{b}$ & $72.96 \pm 0.02^{c}$ & $82.05 \pm 0.03^{d}$ & $88.96 \pm 0.02^{e}$ & $0.0429 \pm 0.04$ \\
\hline Acetone & $42.13 \pm 0.05^{\mathrm{a}}$ & $52.47 \pm 0.03^{b}$ & $75.64 \pm 0.04^{c}$ & $92.48 \pm 0.04^{d}$ & $97.71 \pm 0.03^{e}$ & $0.0317 \pm 0.04$ \\
\hline Ethanol & $43.10 \pm 0.03^{\mathrm{a}}$ & $54.85 \pm 0.04^{b}$ & $82.76 \pm 0.04^{c}$ & $93.76 \pm 0.02^{d}$ & $95.73 \pm 0.02^{\mathrm{e}}$ & $0.0306 \pm 0.04$ \\
\hline BHT & $33.31 \pm 0.02^{a}$ & $54.27 \pm 0.02^{b}$ & $79.06 \pm 0.02^{c}$ & $91.05 \pm 0.05^{d}$ & $93.47 \pm 0.03^{e}$ & $0.0343 \pm 0.02$ \\
\hline
\end{tabular}

Data are presented as means \pm standard deviation of three replicate with significant increases from all samples tested. Superscript a, b, $c$, $d$ and e showed that means \pm standard deviation in the same row with different superscript are significantly different $(p<0.05)$

chelating process [42], their ability to stabilize membranes by decreasing the fluidity of the membranes as well as partitioning flavonoids into the hydrophobic core of the membrane [43] have been considered a contributory mechanism to their antioxidant activities. Since antioxidants are used for the prevention and treatment of free radical-related disorders [44] as well as being essential in the prevention of diseases [5], the high quantity of phenolic and flavonoid contents of Z. mucronata subsp. mucronata may contribute to its potential antioxidant property and curative ability adsorbing and neutralizing free radicals.

\section{Ferric Reducing Antioxidant Power (FRAP)}

The best known antioxidants are phenolic compounds and flavonoids [45-47] exhibiting extensive free radical scavenging activities through their reactivity as hydrogen or electron-donating agents and metal ion chelating properties [7]. In this study, the reductive ability of the extracts reflected the reducing power of the $Z$. mucronata as a potential source of antioxidants. The FRAP assay showed that the antioxidants contained in the extracts acted as reductants in a redox-linked colorimetric reaction [32]. This report agreed with several reports that showed a close relationship between total phenolic content and high antioxidant activity [48-50]. This study, therefore, suggests that the recorded antioxidant capacity resulted from the contribution of different phytochemicals present in the plant and the reducing capacity of each extract may serve as a significant indicator of the potential activity of $Z$. mucronata.

\section{DPPH radical scavenging activity}

The reaction of DPPH with numerous antioxidants has earlier been published and the stoichiometry characterized [51]. The DPPH antioxidant assay is based on the principle that 2,2-diphenyl-1-picryl-hydrazyl (DPPH) is able to decolourise in the presence of free radical scavengers (antioxidants). The color turns from purple to yellow as the molar absorptivity of the DPPH radical at $517 \mathrm{~nm}$ reduces from 9660 to 1640 when the odd electron of DPPH radical becomes paired with hydrogen from a free radical scavenging antioxidant to form the reduced $\mathrm{DPPH}-\mathrm{H}$. The odd electron in the $\mathrm{DPPH}$ radical is responsible for the absorbance at $517 \mathrm{~nm}$ and also for the visible deep purple colour [52]. Antioxidants in the different extracts of $Z$. mucronata subsp. mucronata reacted with DPPH which is reduced to the DPPH-H. Consequently, the absorbencies decreased from the DPPH radical to the DPPH-H formed. The degree of discoloration indicated the scavenging potential of the extracts in terms of hydrogen donating ability. The scavenging ability of this plant was significant and corresponded to the presence of high quantity of phenolic compounds. It is, therefore, reasonable to conclude that high antioxidants in the different extracts of $Z$. mucronata subsp. mucronata have resulted in the high level of DPPH radical scavenged in this study.

\section{ABTS radical scavenging activity}

The fact that phenolic antioxidants have been reported to scavenge $\mathrm{ABTS}^{+}$through hydrogen atom donation [53], electron transfer or even with a combination of the two mechanisms [54] may explain a current interest in the applicability of the $\mathrm{ABTS}^{+}$assay in determining the radical scavenging activities of plant extracts. Like the DPPH assay, ABTS assay measured the total antioxidant activity of the extracts. The different antioxidant activities of the different extracts and the ability of ethanolic extract to exhibit radical-scavenging greater than other extracts may indicate that active compounds of different polarity could be present in $Z$. mucronata. While the hydroxyl $(\mathrm{OH})$ group in aromatic ring have been related to extracts' activity towards ABTS [54], the significant $\mathrm{ABTS}^{+}$scavenging activity of the different extracts may, however, depend on the presence of higher number of hydroxyl groups present in the plant while the high antioxidant activities may be due to their flavonoids and phenolic contents.

\section{Conclusion}

Today, antioxidative properties of extracts from plants have become a great interest due to their possible uses as natural additives to replace synthetic ones. This study was designed to investigate the phenolic contents and evaluate the in vitro antioxidant activities of $Z$. mucronata subsp. 
mucronata. Phenolic compounds, flavonoids and proanthocyanidins were detected in the various extracts of the plant. The antioxidant potential of the extracts indicated that the alcoholic extracts exhibited higher antioxidant activities than the aqueous extracts. The results of FRAP, DPPH and ABTS assays showed that the extracts possess not only the antioxidant activities, but also potent free radical scavenger capability. The antioxidant activity of the extracts correlated well with the total phenolic contents and indicated that phenolic compounds are dominant contributors to the antioxidant activity of the extracts. The high polyphenolic contents, especially flavonoids, responsible for antioxidant activity may be the mechanism of action. $Z$. mucronata subsp. mucronata is a potential free radical scavenger and a useful source of natural antioxidants which may justify the therapeutic effectiveness of the plant.

\section{Acknowledgements}

The authors wish to acknowledge the financial support of the National Research Foundation and the University of Fort Hare. Thanks to Prof. Don Grierson for helping in the identification of the plant.

\section{Authors' contributions}

O०O participated in the design of the study, prepared the extracts, carried out the study and drafted the manuscript. AJA coordinated the study and revised the manuscript. Both authors approved the final manuscript.

\section{Competing interests}

The authors declare that they have no competing interests.

Received: 21 April 2011 Accepted: 16 December 2011 Published: 16 December 2011

\section{References}

1. Bloknina O, Virolainen E, Fagerstedt KV: Antioxidants, oxidative damage and oxygen deprivation stress: a review. Ann Bot 2003, 91:179-194.

2. Farber JL: Mechanisms of cell injury by activated oxygen. Env Health Persp 1994, 102:17-24.

3. Willcox JK, Ash SL, Catignani GL: Antioxidants and prevention of chronic disease. Crit Rev Food Sci Nutr 2004, 44:275-95.

4. Puntel R, Roos D, Paixão M, Braga A, Zeni G, Nogueira C, Rocha J: Oxalate modulates thiobarbituric acid reactive species (TBARS) production in supernatants of homogenates from rat brain, liver and kidney: Effect of diphenyl diselenide and diphenyl ditelluride. Chemico-Biol Interact 2006, 65(2):87-98

5. Di Matteo V, Esposito E: Biochemical and therapeutic effects of the antioxidants in the treatment of Alzheimer's disease, Parkinson's disease, and amyotrophic lateral sclerosis. Curr Drug Targ CNS Neurological Disorder 2003, 2:95-107.

6. Behera BC, Verma N, Sonone A, Makhaija U: Determination of antioxidant potential of lichen. In Usnea ghattensis in vitro. Volume 39. LWT Food Science and Technology; 2006:80-85.

7. Rice-Evans CA, Bourdon R: Free radical lipid interaction and their pathological consequences. Prog Lipid Res 1993, 12:71-110.

8. Sherwin FR: Antioxidant. In Food Additive. Edited by: Branen R. Marcel Dekker, New York; 1990:139-193.

9. Grice HC: Safety evaluation of butylated hydroxytolene (BHT) in the liver, lung and gastrointestinal tract. Food Chem Toxicol 1986, 24:1127-1130

10. Oktay M, Gulcin I, Kufrevioglu Ol: Determination of in vitro antioxidant activity of fennel (Foeniculum vulgare) seed extract. LebensmittelWissenchaft and Technologie 2003, 36:263-271.
11. Ivanova D, Gerova D, Chervenkov T, Yankova T: Polyphenols and antioxidant capacity of Bulgarian medicinal plants. J Ethnopharmacol 2005, 97(1-2):145-150.

12. Chu Y, Sun J, Wu X, Liu R: Antioxidant and antiproliferative activity of common vegetable. J Agric Food Chem 2002, 50:6910-6916.

13. Materska M, Perucka I: Antioxidant activity of the main phenolic compounds isolated from Hot pepper fruit. J Agric Food Chem 2005, 53:1750-1756.

14. Parr AJ, Bolwell GP: Phenols in plant and in man. The potential for possible nutritional enhancement of the diet by modifying the phenols content or profile. J Sci Food Agric 2000, 80:985-1012.

15. Haslam E: Natural polyphenols (vegetable tannins) as drugs: possible modes of action. J Nat Prod 2006, 59:205-215.

16. Tas P, Stopper H, Koschel K, Schiffmann D: Influence of carcinogenic oestrogen diethylstilboestrol on the intracellular calcium level in C6 rat glioma cells. Toxicol In Vitro 1991, 5:463-465.

17. Venter F, Venter JA: Making the Most of Indigenous Trees Briza Publications, Pretoria, South Africa; 2002, 28, (rev. edition).

18. Amusan OO, Sukati NA, Hlophe FG: Herbal remedies from Shiselweni Region of Swaziland. Phytother Recent Prog In Med plants 2005, 10:451-471.

19. Ordonez AAL, Gomez JD, Vattuone MA, Isla MI: Antioxidant activity of Sechium edule (Jacq.) Swart extracts. Food Chem 2006, 97:431-437.

20. Wolfe K, Wu X, Scharffetter-Kochanek K: Antioxidant activity of apple peels. J Agric Food Chem 2003, 51:609-614.

21. Sun JS, Tsuang YW, Chen IJ, Huang WC, Lu FJ: An ultra weak chemiluminescence study on oxidative stress in rabbits following acute thermal injury. Burns 1998, 24:225-231.

22. Ferreira ICFR, Baptista P, Vilas-Boas M, Barros L: Free-radical scavenging capacity and reducing power of wild edible mushrooms from northeast Portugal: Individual cap and stipe activity. Food Chem 2007, 100:1511-1516

23. Jayaprakash GK, Singh RP, Sakariah KK: Antioxidant activity of grape seed extracts on peroxidation models in-vitro. J Agric Food Chem 2001, 55:1018-1022.

24. Liyana-Pathirana CM, Shadidi F: Antioxidant activity of commercial soft and hard wheat (Trichum aestivum L.) as affected by gastric $\mathrm{pH}$ conditions. J Agric Food Chem 2005, 53:2433-2440.

25. Vani T, Rajani M, Sarkar S, Shishoo CJ: Antioxidant properties of the ayurvedic formulation triphala and its constituents. Int J Pharmacog 1997, 35:: 313-317.

26. Sanchez-Moreno C, Larrauri J, Saura-Calixto F: Free radical scavenging capacity of selected red and white wine. J Sci Food Agric 1999, 79:1301-1304

27. Johnstone C, Day JG, Staines H, Benson EE: The development of a 2,2' azinobis-(3-ethyl-benzothiazoline-6-sulfonic acid) radical cation decolourisation assay for evaluating total antioxidant status in an alga used to monitor environmental impacts in urban aquatic habitats. Ecol Indic 2006, 6:280-289.

28. Motalleb G, Hanachi P, Kua SH, Fauziah O, Asmah R: Evaluation of phenolic content and total antioxidant activity in Berberis vulgaris fruit extract. $J$ Biol Sci 2005, 5:648-653.

29. Re R, Pellegrini N, Proteggente A, Pannala A, Yang M, Rice-Evans C: Antioxidant activity applying an improved ABTS radical catión decolorization assay. Free Rad Biol Med 1999, 26:1231-1237.

30. Johnston JW, Dussert S, Gale S, Nadarajan J, Harding K, Benson EE: Optimization of the azinobis-3-ethyl-benzothiazoline-6-sulphonic acid radical scavenging assay for physiological studies of total antioxidant activity in woody plant germplasm. Plant Physiol Biochem 2006, 44:193-201.

31. Larson RA: The antioxidants of higher plants. Phytochem 1988, 27(4):969-978

32. Williams RJ, Spencer JP, Rice-Evans C: Flavonoids: Antioxidants or signaling molecules? Free Rad Biol Med 2004, 36:838-849.

33. Riedel KM, Lee JH, Renita M, Martin SK, St. Schwartz SJ, Vodovotz Y: Isoflavones profiles, phenol content and antioxidant activity of soybean seeds as influenced by cultivar and growing location in Ohio. I Sci Food Agric 2007, 87:1197-1206.

34. Maisuthisakul P, Suttajit M, Pongsawatmanit R: Assessment of phenolic content and free radical-scavenging capacity of some Thai indigenous plants. Food Chem 2007, 100:1409-1418. 
35. Janbaz KH, Saeed SA, Gilani AH: Protective effect of rutin on paracetamoland CC14-induced hepatotoxicity in rodents. Fitoterapia 2002, 73:557-563.

36. Shimoi K, Masuda S, Shen B, Furugori B, Kinae N: Radioprotective effect of antioxidative plant flavonoids in mice. Mutation Res 1996, 350:153-161.

37. Urquiaga I, Leighton F: Plant polyphenol antioxidants and oxidative stress. Biol Res 2000, 33:55-64.

38. Halliwell B, Aeschbach R, Lóliger J, Aruoma OI: The characterization of antioxidants. Food Chem Toxicol 1995, 33:601-617.

39. Wang C, Wixon R: Phytochemicals in soybeans: their potential health benefits. Inform 1999, 10:315-321

40. Steinmetz KA, Potter JD: Vegetables, fruit, and cancer prevention: A review. J Am Dietetic Ass 1996, 96:1027-1039.

41. Cao G, Sofic E, Prior RL: Antioxidant and prooxidant behavior of flavonoids: structure-activity relationships. Free Rad Biol Med 1997, 22:749-760.

42. Kessler M, Ubeaud $G$, Jung L: Anti- and pro-oxidant activity of rutin and quercetin derivatives. J Pharm Pharmacol 2003, 55:131-142.

43. Harborne JB, Williams CA: Advances in flavonoids research since 1992. Phytochem 2000, 55:481-504.

44. Middleton EJ, Kandaswami C, Theoharides TC: The effects of plant flavonoids on mammalian cells: implications for inflammation, heart disease, and cancer. Pharmacol Rev 2000, 52:673-751.

45. Vessal M, Hernmati M, Vasei M: Antidia betic effects of quercetin in streptozocin-induced dia betic rats. Comp Biochem Physiol C D Toxicol Pharmacol 2003, 135:357-364.

46. Molina MF, Sanchez-Reus I, Iglesias I, Benedi J: Quercetin, a flavonoid antioxidant, prevents and protects against ethanol-induced oxidative stress in mouse liver. Biol Pharm Bull 2003, 26:1398-1402.

47. Paganga G, Miller N, Rice-Evans CA: The Polyphenolic content of fruit and vegetables and their antioxidant activities. What does a serving constitute? Free Rad Res 1999, 30:153-162.

48. Amin I, Norazaidah Y, Hainida KIE: Antioxidant activity and phenolic content of raw and blanched Amaranthus species. Food Chem 2006, 94:47-52.

49. Li H, Wang X, Li Y, Li P, Wang H: Polyphenolic compounds and antioxidant properties of selected China wines. Food Chem 2009, $112: 454-460$

50. Williams RJ, Spencer JP, Rice-Evans C: Flavonoids: Antioxidants or signaling molecules? Free Rad Biol Med 2004, 36:838-849.

51. Cuvelier ME, Richard $\mathrm{H}$, Berset $\mathrm{C}$ : Comparison of the antioxidative activity of some acid-phenols: Structure-Activity Relationship. Biosci, Biotech, Biochem 1992, 56:324-325.

52. Kumarasamy Y, Byres M, Cox PJ, Jaspars M, Nahar L, Sarker SD: Screening seeds of some Scottish plants for free-radical scavenging activity. Phytother Res 2007, 21:615-621.

53. Rice-Evans CA, Miller NJ, Paganga G: Structure-antioxidant activity relationships of flavonoids and phenolic acid. Free Rad Biol Med 1996, 20:933-956.

54. Tyrakowska B, Soffers AEMF, Szymusiak H, Boeren S, Boersma M, Lemanska K, Vervoort J, Rietjens IMCM: TEAC antioxidant activity of 4hydroxybenzoates. Free Rad Biol Med 1999, 27:1427-1436.

\section{Pre-publication history}

The pre-publication history for this paper can be accessed here: http://www.biomedcentral.com/1472-6882/11/130/prepub

doi:10.1186/1472-6882-11-130

Cite this article as: Olajuyigbe and Afolayan: Phenolic content and antioxidant property of the bark extracts of Ziziphus mucronata Willd. subsp. mucronata Willd. BMC Complementary and Alternative Medicine 2011 11:130

\section{Submit your next manuscript to BioMed Central and take full advantage of:}

- Convenient online submission

- Thorough peer review

- No space constraints or color figure charges

- Immediate publication on acceptance

- Inclusion in PubMed, CAS, Scopus and Google Scholar

- Research which is freely available for redistribution

Submit your manuscript at www.biomedcentral.com/submit
C Biomed Central 